\title{
APLIKASI KAMUS ISTILAH EKONOMI (INGGRIS-INDONESIA) MENGGUNAKAN METODE SEQUENTIAL SEARCHING
}

\author{
Gunawan $^{1}$ \\ ${ }^{1}$ Fakultas Teknik, Universitas Muhammadiyah Bengkulu \\ Jl. Bali PO BOX 118. Telp (0736) 227665, Fax (0736) 26161, Bengkulu 38119 \\ ${ }^{1}$ base.gugun@gmail.com
}

\begin{abstract}
Abstrak: Seiring berkembangnya dunia perekonomian memunculkan istilah baru dalam dunia ekonomi. Sehingga menimbulkan kesulitan tersendiri bagi masyarakat yang berhadapan dengan istilah-istilah Inggris yang sulit untuk dimengerti. Istilah-istilah dalam ekonomi dapat dicari maknanya dalam sebuah kamus ekonomi. Proses pencarian kata kamus berupa buku dapat memakan waktu yang cukup lama karena proses pencariannya secara manual. Sehingga perlu dibuat suatu aplikasi, salah satunya yaitu aplikasi kamus digital yang dapat mempermudah dalam pencarian kata dan tidak perlu mengeluarkan biaya tambahan untuk membeli kamus. Dalam pembuatan aplikasi kamus digital ini perlu metode yang efektif, karena dalam proses pencarian data merupakan suatu bagian yang penting. Metode yang diterapkan pada aplikasi kamus digital ini yaitu Sequential Searching. Sequential Searching merupakan algoritma pencarian data yang cepat karena proses pencariannya secara terurut. Metode Sequential Searching melakukan pencarian data dengan membandingkan data satu persatu dari kumpulan data yang telah ditentukan sampai data tersebut ditemukan, apabila data tidak ditemukan maka pencarian akan berakhir. Hasil dari penelitian ini berupa Aplikasi Kamus Istilah Ekonomi (Inggris-Indonesia) dengan penerapan metode Sequential Searching yang dapat mencari dan menerjemah kata dengan cepat.

Kata kunci: Kamus, Istilah Ekonomi, Sequential Searching
\end{abstract}

Abstract: As the development of the world economy led to a new term in the world economy. So that is a challenge for people who are dealing with the English terms that are difficult to understand. In economic terms can be searched for its meaning in a dictionary economy. Dictionary word search process in the form of a book can take quite a long time because the search process manually. So that needs to be made an application, one of which is a digital dictionary application that can simplify the search for words to learn and do not need to pay extra to buy a dictionary. In the manufacture of this digital dictionary application needs an effective method, because in the process of collecting data is an important part. The method applied in this digital dictionary application is Sequential Searching. Sequential Searching is a fast data search algorithm because the search process in sequence. Sequential Searching method to search the data by comparing the data one by one from a collection of data that has been determined until the data is found, if the data is not found, the search will end. Results from this study in the form of Application Dictionary of Economic Terms (English-Indonesian) with
Sequential Searching the application method that can search and translate words quickly.

Keywords: Dictionary, Economic Terms, Sequential Searching

\section{PENDAHULUAN}

Ekonomi adalah sebuah bidang kajian tentang pengurusan sumber daya material individu, masyarakat, dan negara untuk meningkatkan kesejahteraan hidup manusia. Seiring berkembangnya dunia perekonomian memunculkan istilah baru dalam dunia ekonomi.

Hal ini cukup menimbulkan kesulitan tersendiri bagi para pelajar, mahasiswa, dosen, pengusaha, maupun masyarakat umum yang secara langsung berhadapan dengan istilah-istilah tersebut terutama istilah-istilah dalam bahasa Inggris. Pada kamus bahasa Inggris, istilah ekonomi tidak dijelaskan secara spesifik tentang makna ekonomi. 
Kamus bahasa Inggris hanya menerjemahkan

kata-kata ke dalam bahasa Indonesia secara umum dan tidak menjelaskan secara detail tentang makna ekonomi.

Para mahasiswa atau mahasiswi yang menempuh pendidikannya di bidang ekonomi dituntut untuk mengerti akan istilah-istilah dalam bahasa ekonomi. Agar kegiatan belajar mengajar dapat berlangsung berjalan secara semestinya dan istilah-istilah tersebut dapat dicari maknanya dalam sebuah kamus bahasa ekonomi.

Kamus merupakan sumber yang memuat istilah, kosakata dan penjelasan maknanya. Kamus bertujuan untuk menyediakan makna yang tepat pada kata yang dicari oleh penggunanya. Proses pencarian kata pada kamus berupa buku dapat memakan waktu yang cukup lama karena proses pencariannya secara manual, dengan membuka perlembar dari huruf A-Z untuk setiap istilah atau kosakata yang digunakan sehingga tidak efektif dan efisien.

Dengan perkembangan teknologi, banyak aplikasi komputer yang dapat digunakan untuk mempermudah pekerjaan dan pembelajaran serta kehidupan sehari-hari. Untuk itu dalam proses pembelajaran perlu dibuat suatu aplikasi, salah satunya yaitu aplikasi kamus digital yang dapat mempermudah dalam menerjemahkan dan pencarian arti kata untuk belajar sehingga tidak perlu mengeluarkan biaya tambahan untuk membeli kamus. Dalam pembuatan aplikasi kamus digital ini, menggunakan metode Sequential Searching, karena metode ini yang paling sederhana pada algoritma pencarian data. Pencarian datadengan metode ini dilakukan dengan membandingkan data satu persatu dari kumpulan data yang telah ditentukan sampai data tersebut sesuai ataupun tidak ada yang sesuai.

\section{LANDASAN TEORI}

\subsection{Kamus}

Kamus digital ialah sebuah buku yang memuat kumpulan istilah atau nama yang disusun menurut abjad dengan menggunakan teknologi komputer dan alat elektronik. Kamus digital lebih mengutamakan pada fasilitas pengola kata elektronis yaitu sebuah fasilitas yang memungkinkan pengguna aplikasi pengolah kata memeriksa ejaan dari dokumen yang ia ketik. Hal ini dapat meminimumkan kemungkinan salah eja kata atau salah ketik [1].

Aplikasi kamus digital adalah suatu aplikasi yang menghasilkan berbagai informasi yang dapat berguna untuk mendukung proses penerjemahan suatu kata atau kalimat secara efektif dan efisien $[2]$.

\subsection{Ekonomi}

Peristiwa pertama yang menandai akan lahirnya ilmu baru yang bernama ilmu ekonomi adalah munculnya istilah ekonomi itu sendiri. Istilah ekonomi lahir di Yunani (Greek), dan dengan sendirinya istilah ekonomi itu pun berasal dan kata-kata bahasa Yunani pula. Asal katanya adalah Oikos Nomos yang berarti tata laksana rumah tangga [3].

Ilmu ekonomi adalah salah satu cabang ilmu pengetahuan yang berdaya upaya untuk memberikan pengetahuan dan pengertian tentang gejala-gejala masyarakat yang timbul karena perbuatan manusia dalam usahanya untuk memenuhi kebutuhan atau untuk mencapai kemakmuran. Dalam hal ini Profesor Paul Anthony Samuelson, seorang ahli ekonomi dari Massachusetts Institute of Technology (MIT), telah mengumpulkan enam buah defenisi dari berbagai ahli lain [3]. 
2.3 Pencarian data (searching)

Pencarian (searching) merupakan tindakan untuk mendapatkan suatu data dalam kumpulan data. Dalam kehidupan sehari-hari, seringkali kita berurusan dengan pencarian misalnya untuk menemukan nomor telepon seseorang pada buku telepon atau mencari suatu istilah dalam kamus. Pada aplikasi komputer, pencarian kerap dilakukan; misalnya untuk mendapatkan data dari seorang mahasiwa, mendapatkan informasi suatu kata dalam kamus digital, mendapatkan nomor telepon berdasarkan suatu alamat atau nama perusahaan [4].

Algoritma pencarian (searching algorithm) adalah algoritma yang menerima sebuah argumen kunci dan dengan langkah-langkah tertentu akan mencari rekaman dengan kunci tersebut. Setelah proses pencarian dilaksanakan, akan diperoleh salah satu dari dua kemungkinan, yaitu data yang dicari ditemukan (successful) atau tidak ditemukan (unsuccessful).

\subsection{Pencarian Sekuensial (Metode Sequential} Search)

Pencarian sekuensial (atau disebut juga pencarian linier) merupakan model pencarian yang paling sederhana yang dilakukan terhadap suatu kumpulan data [5]. Secara konsep, penjelasannya adalah seperti berikut: terdapat $L$ yang merupakan larik yang berisi $n$ buah data $(L[0], L[1], \ldots, L[n-$ 1] dan $k$ adalah data yang hendak dicari. Pencarian dilakukan untuk menemukan

$$
L[i]=k
$$

Dengan i adalah bilangan index terkecil yang memenuhi kondisi $0 \leq k \leq n-1$. Tentukan saja ada kemungkinan bahwa data yang dicari tidak ditemukan. Contoh:

$$
L \leftarrow[10,9,4,6,4,3,2,5]
$$

Dimanakah posisi 4 yang pertama? Dalam hal ini $k$ adalah 4 dan $k$ ditemukan pada posisi dengan indeks berupa 2 .

Pencarian sekuensial atau disebut juga pencarian linier merupakan model pencarian yang paling sederhana yang dilakukan terhadap suatu kumpulan data [5]. Pencarian linier dapat dilakukan pada barisan bilangan yang terurut secara menaik (ascending) atau menurun (descending) ataupun tidak terurut. Pencarian linier dilkukan dengan cara membandingkan data yang dicari $(X)$ dengan data dalam barisan $A[1] \ldots A[n]$ dengan dimulai dari data elemen pertama pada barisan $A$. Jika perbandingan bernilai sama, maka pencarian dihentikan dan dinyatakan sukses. Sedangkan apabila perbandingan tidak bernilai sama maka,

1. Jika data tidak terurut (data acak), maka pencarian akan dilanjutkan ke data selanjutnya.

2. Jika data terurut secara menaik (ascending), maka pencarian hanya akan dilanjutkan ke data selanjutnya yang berada di sebelah kanan data yang sedang dibandingkan apabila data yang dicari $(X)$ lebih besar dari pada yang sedang dibandingkan sekarang.

3. Jika data terurut secara menurun (descending), maka pencarian hanya akan dilanjutkan ke data selanjutnya yang berada di sebelah kanan data yang sedang dibandingkan apabila data yang dicari $(X)$ lebih kecil daripada data yang sedang dibandingkan sekarang.

Jika syarat-syarat di atas dipenuhi, maka pencarian data akan dilakukan sampai data yang dicari $(X)$ ditemukan sehingga pencarian dinyatakan sukses atau sampai elemen terakhir dari barisan A dan tidak ada elemen $A$ yang sama dengan data yang dicari $(X)$ sehingga pencarian 
dinyatakan gagal. Algoritma pencarian linier dapat dituliskan sebagai berikut [6];

Input $\quad$ : Barisan $A[1] \ldots A[n]$ dan $X$.

Output : Pesan $X$ ditemukan atau $X$ tidak ditemukan.

Metoda : Algoritma untuk data tidak terurut (data acak).

Metoda pencarian linier untuk data tidak terurut (data acak) dalam bahasa pemrograman Basic adalah sebagai berikut [6]:

$I=1:$ Ketemu $=$ False

While $(I<=N)$ And Not (Ketemu)

If $(X=A(I))$ Then

Ketemu $=$ True

Else

$I=I+1$

End If

Wend

If (Ketemu) Then

Print $X$, “ ditemukan”

Else

Print $X$, “ tidak ditemukan”

Berdasarkan source code program metode pencarian linier di atas terlihat bahwa inti algoritma pencarian linier adalah bagian perulangan (loop) yaitu While dengan dua kondisi yakni $I<=N$ yang mengontrol agar perulangan jangan sampai melewati batas $N$ dan Not (ketemu) yang mengontrol pencarian apabila data sudah ditemukan maka pencarian tidak perlu lagi dilanjutkan. Jadi, hal yang mengakibatkan proses pencarian keluar dari bagian perulangan adalah barisan sudah habis yakni $I=>N$ atau data yang dicari sudah ditemukan yakni ketemu $=$ True.

\section{METODOLOGI PENELITIAN}

Metode penelitian dalam penyusunan penelitian ini adalah metode pengumpulan data.
Metode ini bertujuan untuk mendukung dalam memperoleh informasi yang dibutuhkan dalam rangka mencapai tujuan penelitian. Tujuan yang dimaksudkan dalam bentuk hipotesis merupakan jawaban sementara terhadap pertanyaan penelitian, yang merupakan elemen penting dalam penelitian. Metode pengumpulan data yang akan digunakan dalam penelitian ini adalah metode studi pustaka, yaitu dengan mempelajari berbagai sumber yang berhubungan dengan penelitian ini dengan membaca dan mempelajari buku-buku, serta menelusuri perpustakaan dan toko-toko buku yang ada di kota Bengkulu yang dapat dijadikan sebagai panduan untuk membangun Kamus Istilah Ekonomi (Inggris-Indonesia).

\section{HASIL DAN PEMBAHASAN}

Dalam pembahasan ini menghasilkan sebuah program yaitu program kamus istilah ekonomi (inggris-indonesia) yang akan memberikan salah satu alternatif aplikasi dalam mengartikan istilah dalam bidang ekonomi.

1. Tampilan Aplikasi

a. Menu Utama

Menu utama merupakan menu yang akan ditampilkan pertama kali ketika kamus istilah ekonomi (inggris-indonesia) ditampilkan.

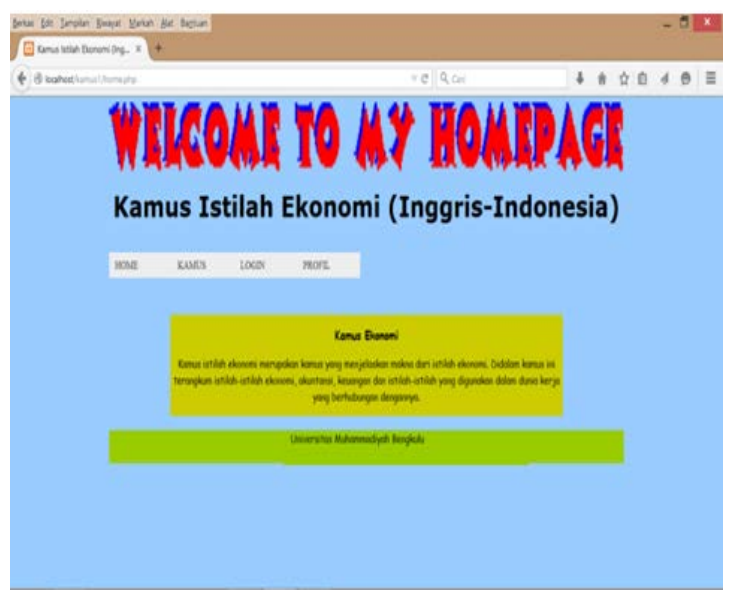

Gambar 1 Menu Utama 


\section{b. Menu Kamus}

Menu Kamus merupakan halaman proses pencarian kata atau istilah. Dalam menu ini, pengguna dapat mencari istilah ekonomi dari bahasa inggris diartikan ke dalam bahasa Indonesia dan dijelaskan dengan kata-kata yang bisa dimengerti pada umumnya. Dalam menu ini terdapat komponen TextField yang dipakai untuk memasukkan kata yang ingin di cari arti dan penjelasannya, komponen TextArea yang dipakai untuk menempatkan hasil dari pencarian kata yang telah di artikan dan dijelaskan ke dalam bahasa indonesia, tombol button (cari) yang jika diklik akan mengartikan kata yang telah di tuliskan di dalam kolom masukkan kata. Tampilan Menu Kamus dapat dilihat sebagai berikut:

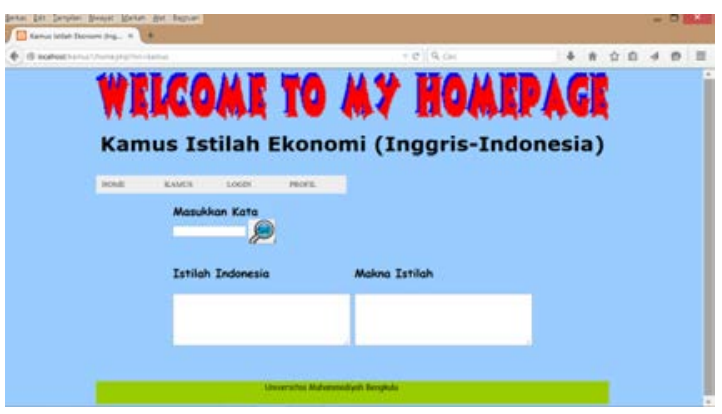

Gambar 2 Menu kamus

\section{c. Menu Login}

Menu login berguna untuk masuk kedalam halaman admin. Dalam menu login ini terdapat kolom username dan password yang harus diisi terlebih dahulu dengan benar agar dapat masuk dan bisa terhubung dengan halaman admin.

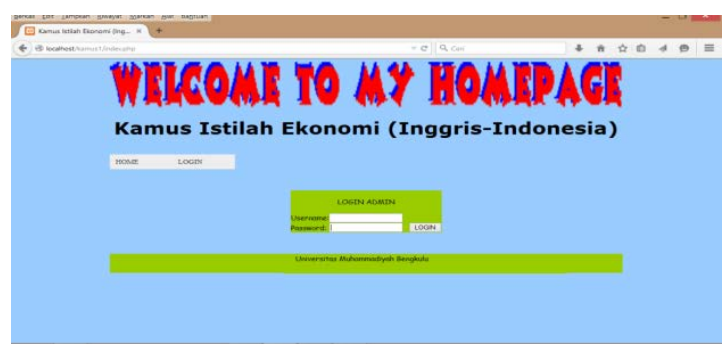

Gambar 3. Menu Login
2. Implementasi Metode Sequential Search

Pencarian sekuensial (atau disebut juga pencarian linier) merupakan model pencarian yang paling sederhana yang dilakukan terhadap suatu kumpulan data. Pencarian beruntun (Sequential) adalah proses membandingkan setiap elemen larik satu per satu secara beruntun, mulai dari elemen pertama sampai elemen yang dicari ditemukan atau seluruh elemen sudah diperiksa.

Dalam pencarian ini proses dilakukan dengan cara mencocokan data yang akan dicari dengan semua data yang ada dalam kelompok data. Proses pencocokan data dilakukan secara berurut satu demi satu dimulai dari data ke-1 hingga data pada urutan terakhir. Jika data yang dicari mempunyai nilai yang sama dengan data yang ada, berarti data telah ditemukan. Tetapi jika data yang dicari tidak ada yang cocok dengan data-data yang ada, berarti data tersebut tidak ada.

\section{Pengujian Aplikasi}

Dalam pengujian pada aplikasi penggunaan kamus ini, hal yang diuji yaitu pengujian kemampuan pencarian dan arti kata atau istilah. Pengujian ini ditujukan untuk mengetahui tingkat keberhasilan yang ingin dicapai, bukan hanya dalam mencari dan mengartikan kata atau istilah namun lebih kepada metode yang digunakan. Pengujian di harapkan dapat memberikan jawaban atas kebenaran dari berbagai macam batasan masalah dan teori yang hendak dilakukan oleh penulis. Pengujian ini dilakukan dengan memasukkan kata atau istilah ekonomi dalam bahasa inggris kedalam form input kata dan klik tombol cari. Dapat dilihat pada gambar berikut: 


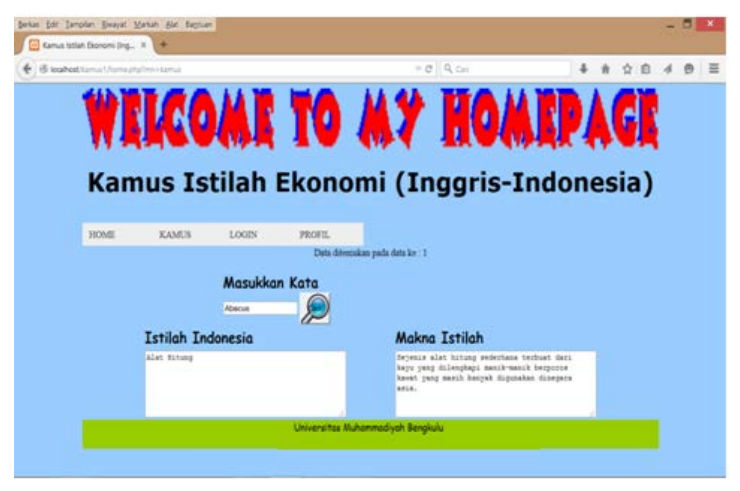

Gambar 4. Pengujian Aplikasi

4. Hasil Pengujian Proses Pencarian dan Penerjemahan

Hal pertama yang harus dilakukan untuk proses pencarian dan penerjemahan adalah membuka menu kamus. Didalam menu kamus ini terdapat kolom masukkan kata, kolom istilah Indonesia dan makna istilah. Untuk mencari dan menerjemahkan suatu kata atau istilah, pengguna hanya perlu menuliskan kata yang ingin dicari terjemahannya misalnya ingin mencari kata “abatement” ketikkan kata ke dalam kolom masukkan kata kemudian klik tombol cari, maka program akan memproses pencarian dengan membaca kata yang ada didalam database. Kemudian menentukan kata yang ingin dicari, mulai dari kata pertama sampai dengan kata terakhir, kata yang dicari dibandingkan dengan masing-masing kata yang ada didalam tabel. Jika kata yang dicari ditemukan maka perbandingan data akan dihentikan dan kata yang dicari akan ditampilkan terjemahannya. Jika kata yang dicari tidak ditemukan maka semua data dalam tabel dibandingkan sampai selesai dan kata yang dicari tidak ditampilkan terjemahannya. Disinilah penggunaan metode sequential searching terjadi. Adapun prosesnya yaitu sebagai berikut:

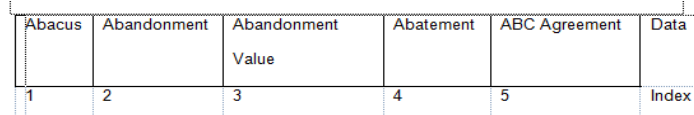

Kemudian program akan meminta data yang akan dicari misalnya kata Abatement ( $\mathrm{i}=$ Abatement ) Iterasi:

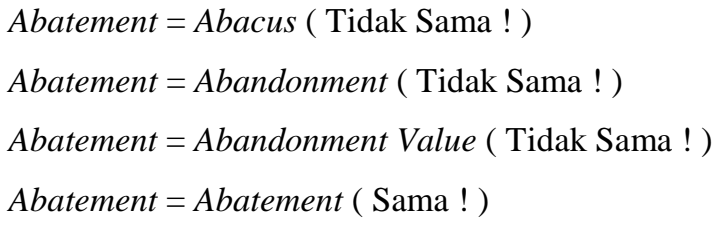

Output : Data ditemukan pada index ke-4.

Jika sampai data terakhir tidak ditemukan kata yang sama didalam database maka pencariannya berakhir dan kata tidak ditampilkan terjemahannya.

\section{PENUTUP}

Hal pertama yang harus dilakukan untuk proses pencarian dan penerjemahan adalah membuka menu kamus. Didalam menu kamus ini terdapat kolom masukkan kata, kolom istilah Indonesia dan makna istilah. Untuk mencari dan menerjemahkan suatu kata atau istilah, pengguna hanya perlu menuliskan kata yang ingin dicari terjemahannya misalnya ingin mencari kata “abatement” ketikkan kata ke dalam kolom masukkan kata kemudian klik tombol cari, maka program akan memproses pencarian dengan membaca kata yang ada didalam database. Kemudian menentukan kata yang ingin dicari, mulai dari kata pertama sampai dengan kata terakhir, kata yang dicari dibandingkan dengan masing-masing kata yang ada didalam tabel. Jika kata yang dicari ditemukan maka perbandingan data akan dihentikan dan kata yang dicari akan ditampilkan terjemahannya. Jika kata yang dicari tidak ditemukan maka semua data dalam tabel dibandingkan sampai selesai dan kata yang dicari tidak ditampilkan terjemahannya. Disinilah penggunaan metode sequential searching terjadi. Adapun prosesnya yaitu sebagai berikut Dari 
keseluruhan penulisan ini, maka dapat diambil kesimpulan bahwa Penelitian ini menghasilkan suatu pencarian kata istilah ekonomi dalam bahasa inggris,pencarian arti kata istilah ekonomi dengan menggunakan aplikasi pencarian data lebih menghemat waktu dibandingkan dengan pencarian dengan menggunakan buku karena dapat memakan waktu yang cukup lama dan penerapan metode Sequential search pada Aplikasi Kamus Istilah Ekonomi (Inggris-Indonesia) ini berjalan dengan baik. Dan dianggap tepat sebagai algoritma pencarian yang digunakan,karena proses pencarian arti kata dalam aplikasi dianggap cepat. Adapun saran dari penelitian ini Program Aplikasi Kamus Istilah Ekonomi (Inggris-Indonesia) tidak mencakup seluruh kata yang ada. Oleh karena itu jika ada kata yang belum terisi diharapkan agar ditambahkan. Diharapkan bisa dikembangkan dengan menggunakan bahasa pemrograman yang berbeda ataupun metode yang berbeda..

\section{REFERENSI}

[1] Agustina, A. (2010). Aplikasi Kamus Digital IstilahIstilah Biologi Dengan Menggunakan Visual Basic 6.0.

[2] Ahmad, F. (2015). Aplikasi Kamus Digital Bahasa Indonesia-Bahasa Arab Dengan Menggunakan Metode Prototyping. Skripsi, Fakultas Ilmu Komputer.

[3] Rosyidi, Suherman.2009.Pengantar Teori Ekonomi (Pendekatan Kepada Teori Ekonomi Mikro dan Makro),Jakarta : Rajagrafindo Persada.

[4] Heriyanto, H. (2015, July). Pencarian Kemiripan Judul Skripsi Dan Abstrak Dengan Metode Exact Match (Studi Kasus Program Studi Teknik Informatika Upn "Veteran" Yogyakarta). In Seminar Nasional Informatika (SEMNASIF) (Vol. 1, No. 1).

[5] Sembiring, Jhoni Pranata .2013. Perancangan Aplikasi Kamus Bahasaindonesia - Karo Online Berbasis Web Dengan Metode Sequential Search, 4(2), 30-31.

[6] Dewi, Irma .2011. Pembuatan Aplikasi Remote Desktop Management Menggunakan Metode Pencarian Linier (Linear Sequential Search), 7(1), 15-16. 